\title{
Sustainable Optimal Design Based on the Upgrade Demand of Macau's Traditional Stalls
}

\author{
Yile Chen ${ }^{\dagger 1,}$, Liang Zheng, ${ }^{1, b}$ \\ ${ }^{1}$ Faculty of Humanities and Arts Macau University of Science and Technology Taipa, Macau, China
}

\begin{abstract}
With the development of the city's economy, Macau's traditional stalls have been unable to meet the current needs. This design research is based on the current status of traditional stalls that are difficult to store, single functional structure, and old-style appearance, combined with the current new requirements of Macau for building a smart city. Foldable solar photovoltaic panels, mobile stall-type $5 \mathrm{G}$ base stations, and live broadcast equipment that echo the trend of the frontline proposed sustainable and optimized designs for upgrading and transformation, echoing the current hotly discussed "stalling economy", and promoting the economy after the epidemic through optimized design recovery. At the same time, it also provides feasible reference suggestions for the future design of Macau stalls.
\end{abstract}

\section{Introduction}

At present, the process of urbanization is accelerating and society is in the era of big data. Traditional industries, traditional facilities, and even traditional culture are bound to be greatly impacted. At the same time, with the proposal of smart city construction, the future must focus on advanced communications. Facility and technical processing methods to deal with traditional stalls, facing the economic recovery after the 2020 epidemic, echo the current hotly discussed "stall economy", how to optimize traditional stall facilities and conduct sustainable research on stalls, It is a question worth considering for planners, architects, and designers.

\section{Macau stall facilities and development history}

The hawkers who set up street stalls in Macau have witnessed the prosperity and development of Macau's history from the time of the Portuguese government to the reunification, and also witnessed the diversified changes in the local stall business. The history of stalls in Macau and the construction of market buildings (as shown in the figure below). Therefore, the traditional stall facilities in Macau have also emerged in response to the needs of residents in the long history and adapting to the development of the times.

Throughout the development history of Macau's stall facilities, it is more focused on urban management and the city's appearance and appearance to restrict the past mobile stalls. Whether it is from the Portuguese government era or after Macau's return to the motherland, Macau has a lot of stall facilities. The distribution is based on the location of the stall, the scope of the stall, the permit the rent, etc., but few people pay attention to the appearance and functional design of the stall facilities of the hawkers, almost all of them are pieced together by the hawkers themselves. The history of the development of stalls in Macau is shown in Table 1 below.

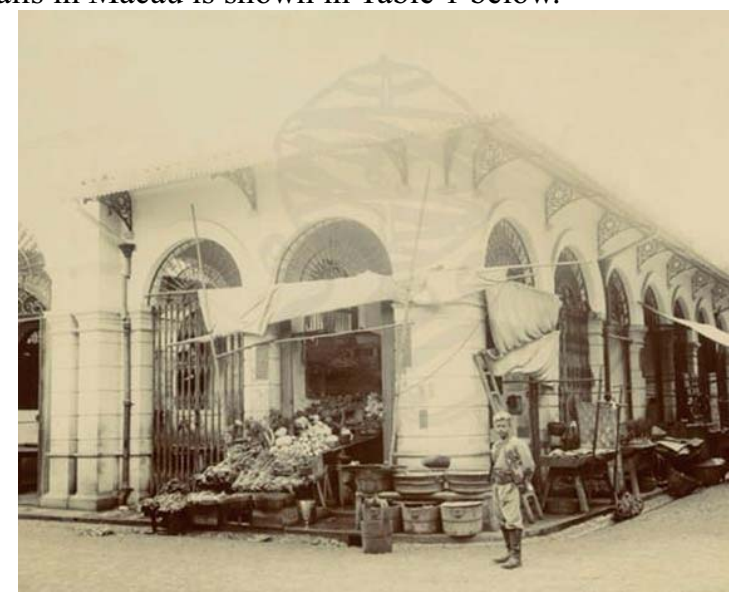

Figure 1: The camp market in the early 20th century [picture source: "Macau Market", page 21] 
Table 1 A brief history of the development of Macau's "stalls"

\begin{tabular}{|c|c|c|}
\hline period & Competent department or agency & Development analysis \\
\hline 18th century & Macau City Hall & $\begin{array}{l}\text { Stalls near the camp market (Mercado de S. Domingos) form a bazaar. } \\
\text { The first to third floors are now for hawker stalls. }\end{array}$ \\
\hline Late 19th century & & $\begin{array}{l}\text { When the Portuguese expanded in Cotai, Taipa, and Coloane, they built } \\
\text { streets on the basis of built-in villages. In the process of urban } \\
\text { expansion, some of the markets in Taipa and Coloane (such as the } \\
\text { Taipa Market) gradually Remodeled and built a municipal market. }\end{array}$ \\
\hline 1868 & & $\begin{array}{l}\text { The Xiahuan Market (at the junction of Hawker Street and Xiahuan } \\
\text { Street) was built, and hawkers set up stalls on the street. }\end{array}$ \\
\hline July 1883 & $\begin{array}{c}\text { Department of Works, Department of } \\
\text { Health }\end{array}$ & $\begin{array}{l}\text { A committee responsible for the study of "improving the material } \\
\text { conditions of the city" was established to manage the sanitary } \\
\text { environment of the market and to provide overall planning guidance } \\
\text { for the construction of the city and the improvement of sanitary } \\
\text { conditions in Macau. }\end{array}$ \\
\hline February 1884 & & $\begin{array}{l}\text { In order to solve the environmental problems caused by hawkers } \\
\text { selling fresh fish in many places, a new fish market was opened. }\end{array}$ \\
\hline 1939 & Portuguese Government & $\begin{array}{l}\text { There are many residents in Bird Park, and the old-style market is } \\
\text { decadent. The Macau and Portuguese government has spent money to } \\
\text { rebuild it into a new-style market. There are also hawker areas around } \\
\text { it. }\end{array}$ \\
\hline Early $1980 \mathrm{~s}$ & No establishment & $\begin{array}{l}\text { A large number of foreigners have moved to Macau, social and } \\
\text { economic development, the number of people has surged, and street } \\
\text { stalls have increased. }\end{array}$ \\
\hline 1987 & Macau City Hall & $\begin{array}{l}\text { The Macau City Hall has established an administrative department } \\
\text { specifically responsible for the management of hawkers, the Mobile } \\
\text { Hawker Auxiliary Group, and has formulated some hawker } \\
\text { management policies accordingly. }\end{array}$ \\
\hline January 1994 & & $\begin{array}{l}\text { The Mercado Municipal do Bairro Iao Hon (Mercado Municipal do } \\
\text { Bairro Iao Hon) was put into use, with stall facilities and a Youhan } \\
\text { Hawker Building, and the Youhan Market Hawker Area was set up } \\
\text { outside the market. }\end{array}$ \\
\hline July 1996 & Macau Civil Affairs Administration & $\begin{array}{l}\text { The "Mobile Hawker Auxiliary Group" was renamed "Hawker Affairs } \\
\text { Office" and is still in use today. It is a department under the Ministry } \\
\text { of Health Supervision. }\end{array}$ \\
\hline 1999 & & $\begin{array}{l}\text { After Macau returned to the motherland, the Basic Law merged the two } \\
\text { city halls of Macau and the island city (including the Taipa Peninsula } \\
\text { and Coloane Peninsula) on January 1,2002, and the Civil and } \\
\text { Municipal Affairs Bureau was formally established. The Hawker } \\
\text { Affairs Office continued to manage hawker stalls. Affairs. }\end{array}$ \\
\hline May 2005 & $\begin{array}{l}\text { Municipal Administration of Macau } \\
\text { Special Administrative Region }\end{array}$ & $\begin{array}{l}\text { The Taishan Market Municipal Complex (with a total area of } 3,520 \\
\text { square meters) was opened. One third of the area is a hawker area, } \\
\text { including fruits, roast meat, ready-to-wear, dry goods, and cooked } \\
\text { food. }\end{array}$ \\
\hline Since 2010 & $\begin{array}{l}\text { Macau Cultural Affairs Bureau, } \\
\text { Taiwan CAMPOBAG }\end{array}$ & $\begin{array}{l}\text { In the first half of the year and the second half of the year, it will be } \\
\text { held once for two weeks each time. The "Macau Settlement of Life" } \\
\text { bazaar will be held to trade creative works of Asian countries and cities. } \\
\text { [4] }\end{array}$ \\
\hline October 2019 & $\begin{array}{l}\text { Municipal Administration of Macau } \\
\text { SAR }\end{array}$ & $\begin{array}{l}\text { After analyzing the "Public Market Management System Law" and the } \\
\text { "Hawker Management System Law" public consultation opinions and } \\
\text { current actual management needs, the two bills will be merged into the } \\
\text { "Public Market and Hawker Management System Law". }\end{array}$ \\
\hline
\end{tabular}

Macau's stall vendors sell a wide variety of goods, which are closely related to the daily life of residents, such as selling brooms, sugarcane, and herbs in old photos, renting comic books, repairing shirts, shovel sharpening scissors, etc. However, with social development and changes in people's needs, many street hawkers have been 
eliminated today, but they have emerged in new formats and sold fashionable goods, which also reflects the changes in the social economy and residents' lives in Macau.

\section{Analysis of the current situation of traditional stalls in Macau}

Although Macau's stall facilities are inseparable from the development of Macau's market architecture [1] [2], compared to traditional stalls, the market has a fixed place, operates indoors, is not susceptible to weather, and has complete facilities. Relatively clean and tidy. The hawkers are mostly open-air operations, and the number of hawkers who apply for a fixed stall that is uniformly allocated by the government (as shown in Figure 2) is very limited.

Therefore, most of the hawkers in Macau are basically mobile vendors, who need to build and prepare their own vehicles, such as folding carts, rack carts, trolleys, and suitcases. Not only the operating conditions are simple, but also easily affected by the weather, it is necessary to build rain sheds, umbrellas, and rain curtains. In addition, practical issues such as power supply, security, transportation, and storage must also be considered. Hawker operators are required to use their imagination and use utensils within their power to transform and optimize the booth (as shown in Figure 3). Also, because the economic model of mobile vendors is mostly personal or family, in order to save costs, the materials and tools used to build stalls are not purchased completely. They are mainly used and recycled waste materials. The types of existing Macau traditional stalls are as follows in Table 2 analysis.

Table 2 Types of traditional stalls in Macau

\begin{tabular}{|c|c|c|}
\hline Types of products sold & Structural features & Main material \\
\hline Cooked food & $\begin{array}{l}\text { The cooked food stalls are based on stainless steel racking carts and have } \\
\text { been modified. Food display and cooking tables are installed on the } \\
\text { platform to facilitate cooking and display samples. Welded sunshade } \\
\text { umbrellas, electric lights and signboards, with armrests on the left and } \\
\text { right sides, can hang packaging bags and seasonings. The space in the } \\
\text { booth is compact, and gas stoves, batteries, food, etc. must be placed. }\end{array}$ & $\begin{array}{c}\text { Modified rack cars, umbrellas, } \\
\text { electric lights, signs, gas stoves, } \\
\text { etc. }\end{array}$ \\
\hline Fruits & $\begin{array}{l}\text { Fruit vendors have a greater demand for fruit display, so the stall carts are } \\
\text { based on stainless steel folding carts, combined with multi-layer shelves } \\
\text { with aluminum alloy brackets, so that there is more space to display } \\
\text { different types of fruits, which are usually heavier The fruits are placed on } \\
\text { the lower layer, and the lighter fruits are placed on the upper layer to } \\
\text { ensure a stable structure. The foam box used to transport fruits is the main } \\
\text { fruit carrier. Some fruits need to be hung, such as bananas, which need to } \\
\text { be tied with a lanyard on the aluminum alloy bracket to hang the fruit. } \\
\text { Secondly, umbrellas and chandeliers are also essential items. }\end{array}$ & $\begin{array}{l}\text { Folding bikes, aluminum alloy } \\
\text { splicing brackets, foam boxes, } \\
\text { lanyards, umbrellas, electric } \\
\text { lights, etc. }\end{array}$ \\
\hline Newspapers & $\begin{array}{l}\text { The mobile newsstand has a simple structure, and is mainly a stainless } \\
\text { steel rack car with a book shelf and a desk in one. The bookshelf part can } \\
\text { be unfolded. After unfolding, the left and right cabinet doors can hang all } \\
\text { kinds of books and reading materials and children's toys. At the same time, } \\
\text { the plane and elevation of the desk will also place and hang all kinds of } \\
\text { books and reading materials, making full use of every space on its surface. }\end{array}$ & $\begin{array}{l}\text { A stainless steel shelf trolley, } \\
\text { umbrella, electric lamp, etc. } \\
\text { which are two-in-one with } \\
\text { bookshelf and desk }\end{array}$ \\
\hline Clothing & $\begin{array}{l}\text { The clothing stalls are mainly composed of floor-to-ceiling hangers, } \\
\text { equipped with universal wheels, umbrellas, and electric lights. Due to the } \\
\text { limited space of the hanger, a storage box on wheels is also available for } \\
\text { inventory. }\end{array}$ & $\begin{array}{c}\text { Movable floor hangers, storage } \\
\text { boxes on wheels, umbrellas, } \\
\text { lights, etc. }\end{array}$ \\
\hline Hardware & $\begin{array}{l}\text { The hardware vendors mainly provide services such as key distribution. } \\
\text { The carts are relatively simple, with a key copy machine and milling } \\
\text { cutters and other tools, and the display racks mainly place various key } \\
\text { blanks and locks. }\end{array}$ & $\begin{array}{c}\text { Key duplicators, milling cutters, } \\
\text { display stands, umbrellas, } \\
\text { electric lights, etc. }\end{array}$ \\
\hline Fresh & $\begin{array}{l}\text { Since live fish cannot be killed outdoors in Macau, the fresh food vendors } \\
\text { mainly sell ornamental fish. The stall is composed of multi-layer shelves } \\
\text { as the main body, and one or more fish tanks are placed on each shelf. } \\
\text { There is an electric light on the top of the fish tank and an air pump inside. } \\
\text { The remaining corner space is for supporting products such as fish feed. }\end{array}$ & $\begin{array}{l}\text { Multi-layer shelves, fish tanks, } \\
\text { umbrellas, electric lights, etc. }\end{array}$ \\
\hline
\end{tabular}




\begin{tabular}{|c|c|c|}
\hline Groceries & $\begin{array}{c}\text { Grocery stalls are similar to newsstands, but the difference is that the } \\
\text { cabinet doors of the shelf have a certain depth, and all kinds of small } \\
\text { commodities or drinks can be placed. In addition, individual vendors will } \\
\text { purchase a small freezer to store ice cream and cold drinks. }\end{array}$ & $\begin{array}{c}\text { Two-in-one stainless steel rack } \\
\text { cart with bookshelf and desk, } \\
\text { refrigerator, umbrella, electric } \\
\text { light, etc. }\end{array}$ \\
\hline Drinks & $\begin{array}{c}\text { Beverage vendors mainly sell herbal tea. The notable feature is that there } \\
\text { are several large heat preservation pots on the shelf cart, which are labeled } \\
\text { with the names of different types of herbal tea, and paper cups and other } \\
\text { heat preservation pots are placed in the shelf cart. }\end{array}$ & $\begin{array}{c}\text { Stainless steel rack carts, } \\
\text { insulation pots, umbrellas, } \\
\text { electric lights, etc. }\end{array}$ \\
\hline
\end{tabular}

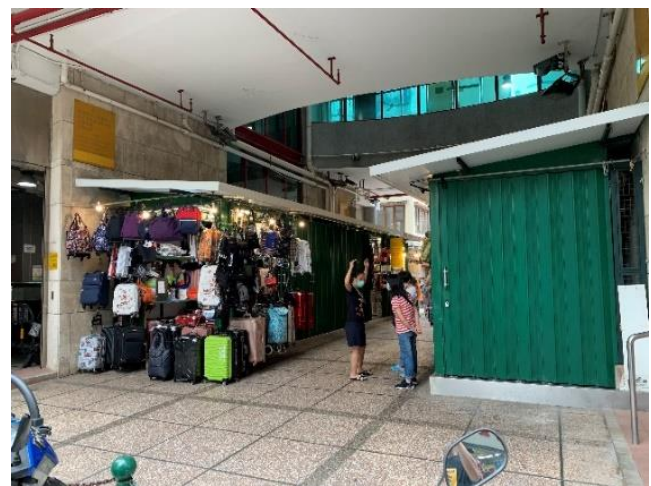

Figure 2: Hawker area around the camp market [picture source: self-photo]

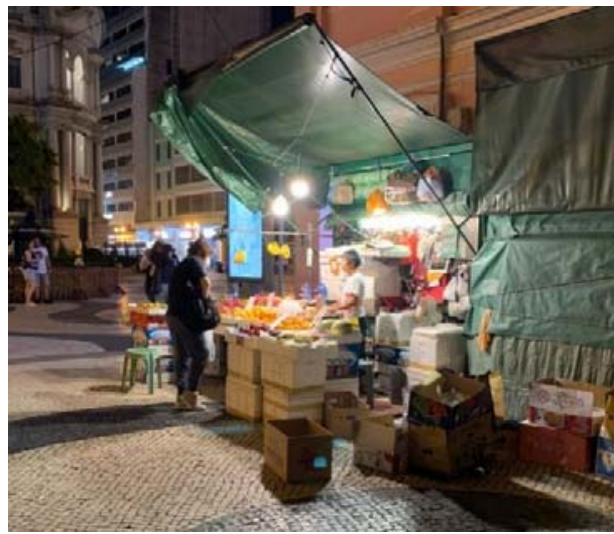

Figure 3: Mihu Alley Street Vendor[picture source: self-photo]

There are many types of stalls in Macau, with various styles of stalls. They are mainly located in the historical city and surrounding areas of the Chamber, Xiahuan Street, and Hebian New Street. Through field research, it is found that traditional stalls have a certain degree of convenience and mobility, which is convenient for stall owners to adjust the venue flexibly in order to face more people and increase the exposure of stalls. In addition, due to the subtropical monsoon climate in Macau, the summer is hot and rainy. Vendors usually install large umbrellas or choose roofed arcades to protect themselves from the rain. For vendors operating at night, they will be equipped with lighting equipment. The photos of the main types of existing Macau stalls are summarized in Figure 4 below.

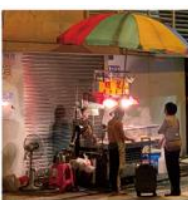

Cooked food vendors

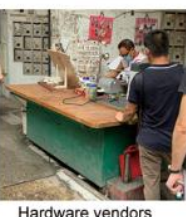

Hardware vendors

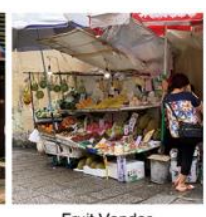

Fruit Vendor

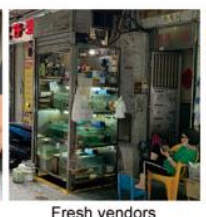

Fresh vendors
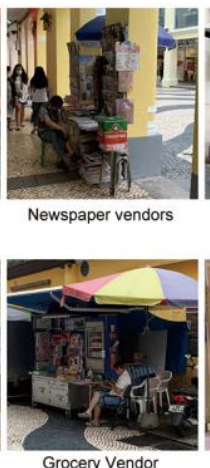

Grocery Vendor

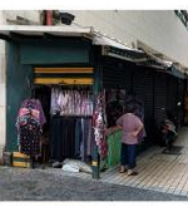

Clothing vendors

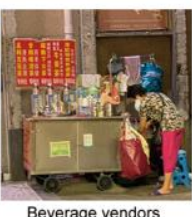

Figure 4: The main types of existing traditional stalls in Macau [picture source: self-photo]

\section{Sustainable optimization design analysis}

The design focuses on the current situation of traditional Macau booths that are difficult to store, have a single functional structure, and an old-style appearance. In terms of sustainable optimization design, the first introduced foldable solar photovoltaic panels, which can be used as wind and rain shields, and can be used for self-use when setting up stalls. Electricity usage. [3] [4]

Currently, Macau is vigorously promoting the construction of a smart city, and as early as September 2018, Macau Telecom (CTM) Vice President of Network Services Liang Peixiong pointed out at a press conference on Macau $5 \mathrm{G}$ that $5 \mathrm{G}$ networks have high transmission rates and low latency The characteristic means that it needs a higher frequency spectrum, and the number of $5 \mathrm{G}$ base stations will be more. Due to the objective conditions of Macau, the deployment of 5G base stations will be a great challenge for operators. Therefore, in the design of this stall, the $5 \mathrm{G}$ base station is placed on the roof of the stall, making it a mobile stall-style base station deployment model, contributing its own strength to the current SAR government's vigorous promotion of smart cities and $5 \mathrm{G}$ construction.

For roadside vendors, one of the more worrying issues is the health, safety and quality of the food they sell. In 2017, after Chengdu and Shunde, Macau became the third Chinese city to be listed by UNESCO as the global creative "gourmet capital". Due to the long history of local Chinese, Portuguese, and Southeast Asian immigrants living together, different cuisines have been converged, and a large number of delicacies are distributed among the stalls on the streets. In order to allow consumers to use it 
with confidence, the design of this booth has added live broadcast equipment that echoes the trend of the front line, which can be sold online and offline at the same time and show the production process. The advantage of live broadcasting is not only that the process can be seen intuitively, but the income from live broadcasting can also subsidize part of the income from the stall.

In addition, the foldable wooden boards, side-hung grids, built-in storage boxes, detachable folding booth rest stools, booth sales advertising screens, built-in food waste recycling bins and other equipment, the main color of the special zone also represents environmental protection The elements of green and Portuguese patterns make the traditional stalls have an optimized design, which is convenient to fold and store them home, and also allows the remaining of the stalls to enter the small-scale food waste recycling mode.

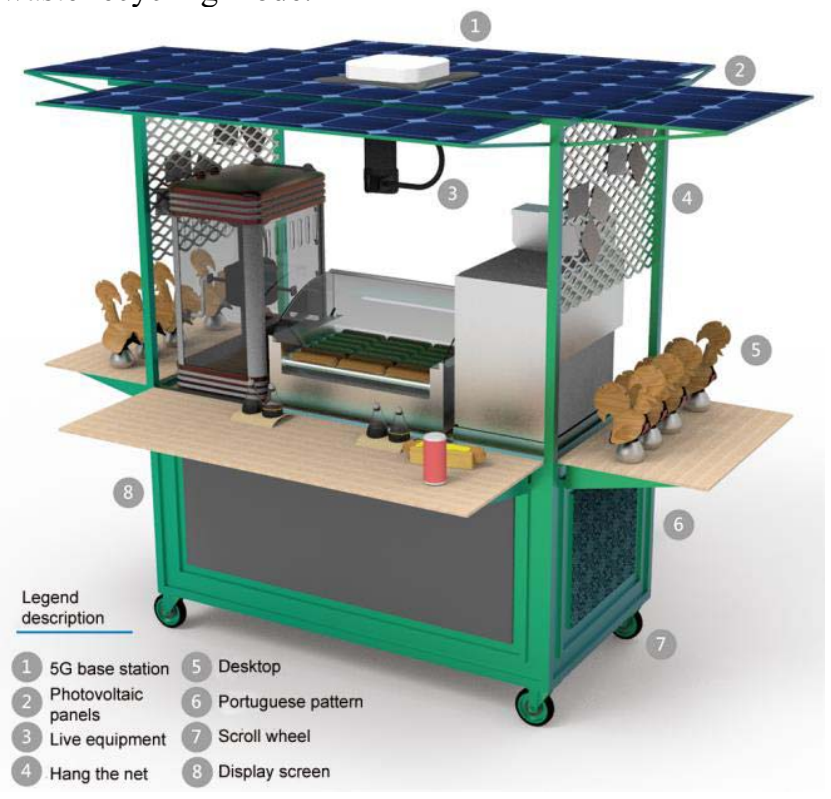

Figure 5: After the optimized design of the stall cart [picture source: self-painted]

The grids on both sides of the stall can hang and sell local characteristic commemorative postcards; open the tables on both sides to place and sell all kinds of sundries; the disassembled folding board can be used as a rest stool for hawkers. After the hawker finishes setting up the stall, the stall cart can fold up the surrounding panels for easy storage, and the size is consistent with the entrance and exit of the elevator door of the local Macau house, which is convenient for the hawker to push home after closing the stall. Detailed illustrations are shown in Figure 5 above and Figure 6-9 below.

As far as Macau is concerned, the optimized stall is easier to disassemble, retract and fold compared to traditional stalls, has a lightweight body that is easy to move, has certain rain and sun protection facilities, and also has more storage space. 5G mobile stalls help the construction of a smart city in Macau, and small food waste recycling bins also help the sustainability plan of the Macau Environmental Protection Agency. It is a bright design that meets the needs of the current Macau society.

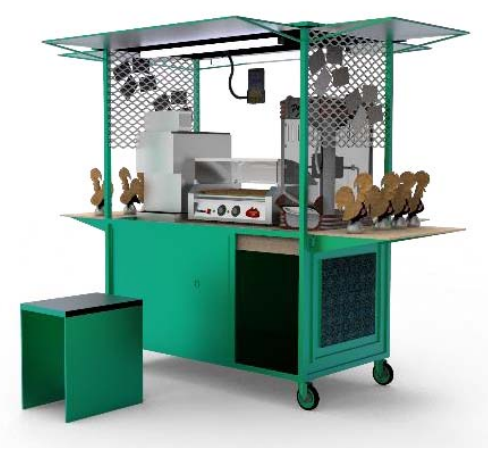

Figure 6: Design renderings of stall carts [picture source: selfpainted]

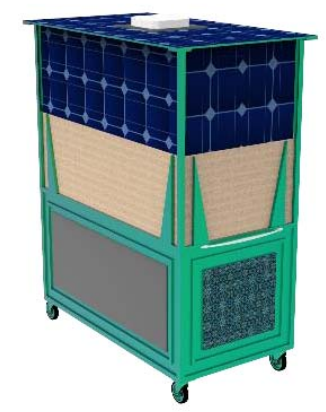

Figure 7: The effect picture of the stall car after storage [picture source: self-painted]

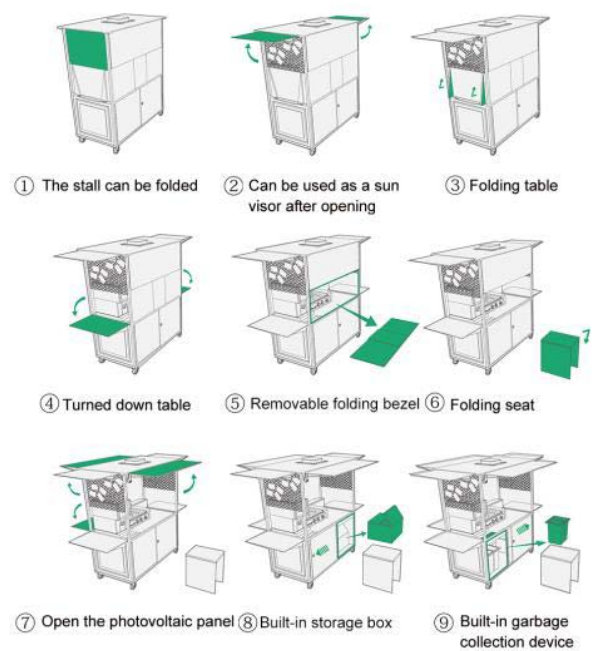

Figure 8: Schematic diagram of stall cart combination [picture source: self-painted] 


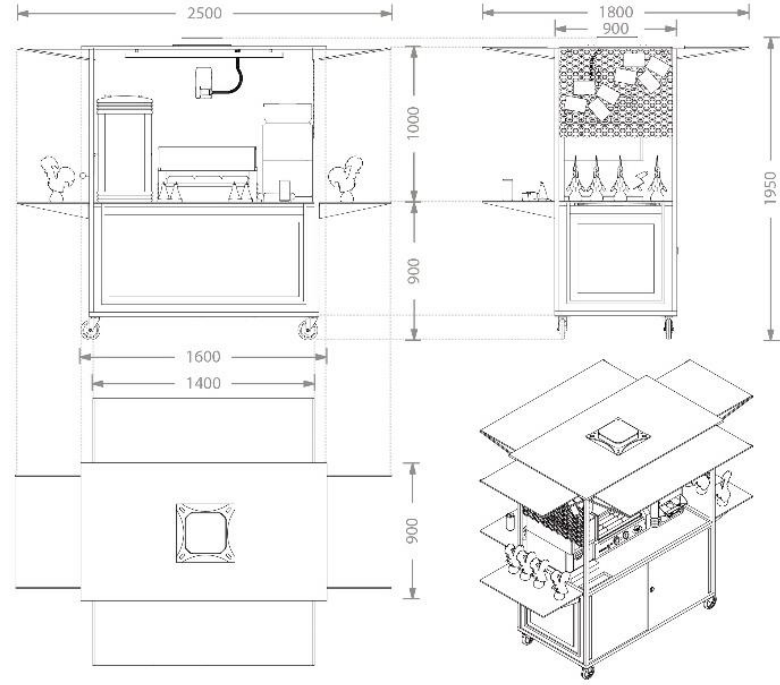

Figure 9: Main dimensions of the stall cart [picture source: self-painted]

\section{Principles and application analysis of stall design}

\subsection{Choice of cart space}

Different industries have different requirements for the venues for stalls. A suitable venue can double the operating efficiency of stalls and help improve the comfort of the stall owners. According to the actual situation in Macau and the real demand for stalls, it can be considered in the following aspects.

5.1.1 Distance of replenishment. Macau is a worldfamous tourist city with many tourists and a large flow of people. For commodity vendors, a suitable replenishment distance can save time, transportation and unexpected costs. Time cost refers to the time cost of replenishing a product when a product is out of stock during the sales process. Because the peak sales period is limited, the quick replenishment within a limited time will help increase turnover. Transportation cost refers to the manpower and material resources required to transport commodities, such as fruits and fresh commodities, which may require transportation vehicles and personnel assistance during long-distance transportation, thereby increasing operating costs; unexpected costs refer to, In the event of extreme weather, there may be accidents such as long distances, which may make it impossible to collect the stalls in time, resulting in additional losses caused by accidents such as damage to goods.

Therefore, choosing a venue close to the replenishment point will help reduce unnecessary additional costs and reduce the operating burden of stalls.

5.1.2 Distance of public toilets. According to statistics from the Municipal Administration of Macau, there are
127 public toilets in Macau. Compared with the land area of 32.9 square kilometers in Macau, the number of public toilets is not abundant, and the use of toilets is a physiological need for people. According to research, a person urinates about 8 times a day. If you cannot go to the toilet in time and reach the limit of the physiological capacity of the bladder, it will cause reflux kidney disease and pyelonephritis, which will cause kidney failure and other diseases, which will seriously affect your health.So the distance of the toilet is also within the range of site selection. Proper toilet distance can ensure the health of stall owners, and the toilet itself is also one of the crowds. Conditional vendors can sell products that match the toilet, expand the types of goods, and improve business efficiency.

\subsubsection{Close to the existing street vendor business} district. Macau has a long history of stalls, and there are many business districts with stalls, such as Xiahuan Street, San Ba Tsai Street, Senado Square, etc. The formation of the existing mature business district represents that the venue has significant commercial potential. Under the agglomeration effect, the business district itself also has the function of attracting people. Setting up a stall in a mature business circle can take a ride in Vaughan, or even refer to the goods sold in the business circle, and complement and complement products with it, avoid vicious competition, and achieve mutually beneficial results.

5.1.4 Compliance with laws and regulations. It is necessary to strictly abide by relevant laws and regulations before setting up the stall, otherwise it will cause certain risks and hidden dangers to the stall, resulting in fines, suspension of business, and confiscation of the stalls. In this preparation, data collection and integration should be carried out, and the municipal, sanitation and fire protection regulations should be consulted. Certain industries also need to be registered in advance, such as food processing and sales, which require sanitation registration and inspection. Observing the laws and regulations of the city can reduce unnecessary business risks, ensure the maximization of profits, and reduce unfavorable factors.

\subsection{Assessment of the adaptability of the stall and the venue}

5.2.1 Size considerations. The size of the stall should conform to the scale factor of the city. According to the Macau Street Network, there are 1,255 streets in Macau. The widest street is Avenida de Notre Dame Bay, about 41 meters, and the narrowest street is in a fishing net, about 1 meter wide. The closed width of the stall is 0.9 meters, and it can pass smoothly even in the narrowest streets.

5.2.2 Light considerations. A bright business environment is conducive to improving consumer comfort. 
Inside the booth, there is a LED light bar to provide good lighting support for the business. In addition, the top of the stall is equipped with photovoltaic panels, which can use solar energy to store energy during the day, and use lighting equipment at night to achieve the design goal of zero energy consumption.

5.2.3 Comfort considerations. After investigation, it is found that most of the existing stall vehicles do not have seats, because carrying seats will increase the transportation burden. In this design, the seat and the stall are cleverly combined, and the stall owner can easily install, remove, fold and sit down for use. Improve the comfort of stalls and people-oriented design.

\section{Conclusion}

Macau has transformed from a small fishing village into an international city, a world leisure and tourism center, and a Sino-Portuguese platform. It has also experienced a past where the streets and lanes are full of stalls, and this year has experienced a sudden new crown virus epidemic. Although the SAR government has launched a tens of billions of anti-epidemic funds, a cash sharing plan, and the issuance of consumer vouchers, it is actually difficult to really save the economy by relying on aid-type subsidies. To support the family, but also to maintain the characteristics of the streets of Macau. Traditional stalls are difficult to develop further under the status quo, and based on the environment of stall economy, Macau market culture, tourism night market economy, smart city 5G construction, and sustainable urban development of kitchen waste recycling, this optimized stall Design has a certain reference research value of timeliness and social adaptability.

\section{REFERENCES}

1. Chen Yile, Zheng Liang (2020). An Analysis of the Market Culture of Macau's Stall Facilities and Urban Public Space: Taking the Historic District of Macau Peninsula as an Example. Beauty and Times (Urban Edition), 6, 1-7.

2. Chinese government website, Li Keqiang praised the stall economy and the small shop economy: it is the fireworks of the world and the vitality of China, http://www.gov.cn/xinwen/202006/01/content_5516569. html

3. People's Daily Online, Keep the "road market" and make the city more dynamic, http://liuyan.people.com.cn/n1/2020/0529/c5827831728428.html

4. Macau Municipal Administration, Markets and hawkers,

https://www.iam.gov.mo/c/market/scope 